\title{
eCRM: Measuring the effectiveness of web channels
}

\author{
RECEIVED (IN REVISED FORM): 4 MAY, 2000 \\ Wendy Hewson* and Fiona Coles \\ *Hewson Group, Carlton House, Market Place, Reepham, Norfolk NRIO $4 \mathrm{~J}$ \\ e-mail: wendy@sistrum.org
}

\section{Abstract}

Since 2000, on-line companies have been haemorrhaging cash in a bid to attract new customers, some spending as much as $£ 46$ to get $\mathcal{E}_{1}$ in gross profits. This paper provides evidence of the ineffectiveness of this sales and marketing spend. Of every 12 serious sales leads that are pulled into UK websites, only one is being handled well with the other 11 effectively being wasted.

Given that the UK represents a considerable proportion (about 35 per cent) of the spend on CRM in Europe, CRM would be expected to be doing well. This is not so. Far from excelling at managing relationships at all touchpoints, in the UK companies stumble at one of the simplest challenges: how to handle e-mail leads from hot prospects.

This paper presents the findings from the third Sistrum survey into on-line service in the $U K$ and examines the implications for six key industry sectors. At a time when real structural differences in the dynamics of US and European economies are being highlighted careful thought needs to be given not just to high-flown 360-degree CRM philosophies but also to the realworld execution of customer management strategies. Hewson Group believes the state- ments contained in this analysis are based on accurate and reliable information. However, because our information is provided by various sources including third parties, we cannot warrant that this analysis is complete and error free. Hewson Group disclaim all implied warranties, including without limitation warranties of merchantability or fitness for a particular purpose. Hewson Group shall have no liability for any direct, incidental, special or consequential damage or lost profits.

\section{INTRODUCTION}

The third Sistrum survey into online customer service provides damning evidence of the ineffectiveness of on-line companies' sales and marketing spend.

On-line companies are haemorrhaging cash in a bid to attract new customers, some spending as much as $\mathcal{E} 46$ to get $\mathcal{K}^{1}$ in gross profits. Yet this frenzy of activity is hugely ineffective - of every 12 serious sales leads that are pulled into UK websites, only one is being handled well with the other 11 effectively being wasted. The much vaunted waste in traditional mass-market advertising, a mere 50

\author{
Wendy Hewson \\ is Research \\ Director for \\ Sistrum, The \\ European Centre \\ for CRM issues \\ and for the last 18 \\ months has been \\ developing the \\ 'UK Score on the \\ On-line Doors' \\ research \\ programme into \\ on-line service. \\ Fiona Coles has \\ undertaken \\ extensive research \\ into the state of \\ on-line pre-sales \\ service offered by \\ companies who \\ actively promote \\ their websites in \\ their advertising. \\ She has also \\ researched how \\ the top \\ performing \\ companies achieve \\ excellent results \\ consistently.
}


per cent, is dwarfed by the on-line industry's 92 per cent. This one in 12 average conceals a more worrying economic truth. Once the survey results are broken down it is found that 41 per cent of companies are making no effort to respond to an urgent request from a potential buyer.

The following section describes the survey method and then results are described and their implications discussed.

\section{ABOUT THE SURVEY}

The full survey is conducted quarterly and the latest versions are free to Sistrum members, www.sistrum.org.

Conducted with eGain Communications on behalf of Sistrum, The European Centre for Customer Relationship Management Excellence, the survey contacted more than 185 major UK companies including many members of the 'Times Top 100', and leading representatives of the following sectors: contract hire, business travel, personal computers and printers, Internet service providers, business schools, personal finance, investment and stock dealing, adult entertainment, branded clothes and shoes, watches, cameras and mobile phones, food, drink and cosmetics and automotive industries. The researchers put themselves in the position of someone who wants to buy a product or service urgently and would prefer to use the Internet to do so.

Posing as mystery shoppers, researchers attempted to purchase products or services from companies using their advertised web address or, in a minority of cases, their e-mail. Only those companies that are actively promoting their website in UK national television and print advertising were approached. Results were analysed across 12 sectors:

- business: business schools; car contract hire; business travel and conferences; personal computers and printers; Internet service providers

- consumer: branded clothes and shoes; adult entertainment; watches and mobile phones; personal finance; investment and stock dealing; home furnishings; food, drink and cosmetics; cars.

In all sectors, care was taken to ensure that the appropriate buying signals for high-value customers were given. In general, website forms or e-mails were used to request product brochures and to ask questions on specific products and services. For business travel, for example, questions were asked about availability of conference accommodation and the need for inoculations. In the automotive sector, brochures on specific car models and test drives from the nearest local dealer were requested.

Responses were ranked on the time taken to reply and the quality of answer. Where brochures were received, the accuracy of the name and address information used was also noted versus that which had been supplied. 
The results for each sector refer to 'best' and 'worst'. The best companies are those which provide an effective response to on-line sales enquiries in terms of their speed and accuracy of response to both questions and brochure requests. For the $\mathrm{UK}$, this pragmatic measure means they provide good answers to questions within two working days and send out any brochures or collateral within three. The worst companies are those which did not respond at all.

The survey was conducted between April and June 2000 and 187 companies were included.

\section{RESEARCH FINDINGS}

Things got significantly worse for UK on-line between December 1999 and June 2000. Of over 180 (180) major UK companies who actively promoted their website in their television and print advertising, 11 out of 12 are wasting sales leads. (December 1999 figures are given in brackets.)

The much vaunted waste in traditional mass-market advertising, 50 per cent, is dwarfed by the on-line industry's 92 per cent. A swift and accurate response to enquiries is at the top of most Internet customers' requirements. The survey found that 8 per cent of companies provide an effective response to an urgent request from a potential buyer; 51 per cent attempt to, providing a poor response at considerable cost; and a staggering 41 per cent (28 per cent) of companies do nothing at all.
For the UK, an effective response is considered to be answering a potential customer's questions within two working days and sending out any brochures or collateral within three. It is a combination of good literature fulfilment and response to e-mail queries. Each of these are looked at in turn.

\section{LITERATURE FULFILMENT}

Overall brochure dispatch has deteriorated, taking an average of 5.1 (4.8) days from request to receipt. Worse still, just 52 per cent (50 per cent) of product brochures requested (15 per cent had no way of requesting a brochure) were received. Of the brochures requested:

- 14 per cent (20 per cent) were received within two working days

- a further 24 per cent (14 per cent) in two to five days

- 14 per cent (15 per cent) took more than five days

- 48 per cent (50 per cent) were never received.

There is a schism opening between those automated companies able to dispatch literature the same/next day (cars and home furnishings were particularly efficient) and the 'also rans' which are taking considerably longer.

\section{RESPONSE TO E-MAIL QUERIES}

Not all companies are inviting e-mail enquiries, 23 per cent (5 per cent) offered no way of asking questions 
and 4 per cent (22 per cent) of the companies' e-mail addresses did not work. Of those companies, 41 per cent (28 per cent) did not respond to the e-mail. If they did answer, they answered quickly. Of the companies questioned:

- 42 per cent (49 per cent) responded the same or next day

- 10 per cent (18 per cent) responded in two to five days

- 7 per cent (5 per cent) took more than five days to respond.

This is a decrease in both the numbers of companies responding and speed of response in January.

The quality of the responses has also deteriorated and continues to be a significant issue:

- 32 per cent (40 per cent) of questions were answered fully

- a further 17 per cent (27 per cent) were answered in part

- 10 per cent (5 per cent) received a completely inappropriate answer.

\section{Highest response rates to queries}

Adult entertainment, business travel, home furnishings, branded clothes, the business schools and food, drink and cosmetics replied to a higher than average proportion of e-mails. The business schools and food, drink and cosmetics were in the worst sector in the earlier survey. The worst sectors in the later survey were contract hire (no change), Internet service providers, and computers and printers.

\section{Fastest responses to queries}

The fastest responses (the highest percentage of e-mails replied to in the same or the next working day) came from adult entertainment, branded clothes, food, drink and cosmetics and home furnishings. The slowest responses came from automotive and business travel.

\section{Best answers}

The most complete answers came from the adult entertainment, the business schools and business travel sectors. Food and drink, home furnishings and watches and mobile phones provided the highest number of worst answers. Once again the adult entertainment sector is the on-line query winner, providing the fastest and most appropriate responses.

\section{The best performing companies}

The best performers included:

- the Fordham University, USA, which provided an excellent e-mail response the same day it was requested, so reducing the need to send a brochure from the USA to England

- Crown, which passed the request to a local dealer who contacted the researchers the next day. This lead for a high-margin fitted kitchen was treated seriously. The researchers received a brochure from the local dealer within two days and, 'to ensure that we had the information needed', Crown also e-mailed them 
with details of the local dealer and local showrooms

- Johnson Fry, Schroders, Sharepeople.com and Gartmore which all answered the researchers' questions fully

- Hewlett Packard with an outstanding website with the emphasis on buying online.

- Sharepeople.com, placed 27th in a Sunday Times e-league survey of Europe's top 100 Internet ventures, was also featured.

\section{The worst performing companies}

Contract hire were overall first in this category followed by the Internet service providers and then the computers and printers. All these sectors are guilty of poor performance by not fulfilling brochure requests and not fully responding to questions, if at all.

\section{RESULTS BY INDUSTRY SECTOR}

\section{Business travel and conferences}

The ten companies surveyed were: Brittany Ferries, ExCel, Virgin Trains, $\mathrm{P} \& \mathrm{O}$ Stena Line, GO, Lufthansa, Barbizon Hotel, Heritage Hotels, Sea France, Posthouse.

Typical questions asked were:

'I am organising a conference for 80 delegates in London. Will a suitable room and four smaller rooms for break out groups be available for this time? The party will include two disabled people in wheelchairs, can you tell me if wheelchair access is planned for all areas of the venue?'

'We have five executives who will be travelling to France on a weekly basis one of which requires wheelchair access. Can you tell me if the club lounge on the $7 \mathrm{am}$ crossings from Dover to Calais will have wheelchair access. How many desks are provided in the business lounge and can they be booked in advance?'

\section{Sector summary}

In January results for the business travel sector were appalling across the board with exceptionally slow brochure dispatch (suicide in a fast moving sector). Four months later, however, there was a marked improvement in both the response to queries and literature fulfilment. The full results are given in Table 1.

All of the companies asked questions responded with almost half providing high quality answers rapidly. In this sector, and in personal finance, is being seen the emergence of an explicit strategy to point Web users with complex enquiries towards the telephone while making it impossible to enquire further on-line. A third of these provided a group reservations number.

There are no best performing companies in this sector and one worse performer, a web-centric travel company which offered no way of asking questions or requesting a brochure although they did offer a range of telephone numbers. 


\section{Table 1}

\section{BUSINESS TRAVEL AND CONFERENCES}

\begin{tabular}{|c|c|c|c|}
\hline & Sector & Sector & All \\
\hline & December & May & Companies \\
\hline & 1999 & 2000 & May 2000 \\
\hline Per cent advertising websites only & 100 & 100 & 78 \\
\hline Per cent advertising e-mail addresses only & 0 & 0 & 6 \\
\hline Per cent advertising both & 0 & 0 & 16 \\
\hline \multicolumn{4}{|l|}{ Contactability } \\
\hline Per cent website did not work & 10 & 0 & 6 \\
\hline Per cent e-mail did not work & 30 & 0 & 4 \\
\hline Per cent no way of asking questions & 0 & 10 & 23 \\
\hline Per cent no way of requesting brochures & 0 & 10 & 15 \\
\hline \multicolumn{4}{|l|}{ Request for brochures } \\
\hline Average number of days to receive brochure & 10.0 & 5.4 & 5.1 \\
\hline Per cent brochures not received & 57 & 44 & 48 \\
\hline Per cent received next day & 0 & 0 & 1 \\
\hline Per cent received within two working days & 0 & 0 & 13 \\
\hline $\begin{array}{l}\text { Per cent received between two and five } \\
\text { working days }\end{array}$ & 0 & 44 & 24 \\
\hline Per cent received after five working days & 43 & 11 & 14 \\
\hline Per cent with correct name and address & 67 & 60 & 91 \\
\hline \multicolumn{4}{|l|}{ Request for product service information } \\
\hline Per cent of organisations asked questions & 70 & 90 & 77 \\
\hline Per cent where full answers received & 14 & 44 & 32 \\
\hline Per cent where part answers received & 43 & 33 & 17 \\
\hline Per cent where inapproproate answer received & 14 & 22 & 10 \\
\hline Per cent where no answer was received & 29 & 0 & 41 \\
\hline Per cent answering the same day & 57 & 44 & 28 \\
\hline Per cent answering the next working day & 0 & 33 & 15 \\
\hline Per cent answering the second working day & 14 & 11 & 6 \\
\hline Per cent answering two to five working days & 14 & 0 & 4 \\
\hline Per cent answering after five working days & 0 & 11 & 7 \\
\hline Per cent best & 0 & 0 & 8 \\
\hline Per cent worst & 30 & 10 & 41 \\
\hline
\end{tabular}




\section{Contract hire}

The 21 companies surveyed included: Apple, Cygnet, AVC, Brooklands, Car Myke, Premier, Sabre, Dixon, Countrywide, Fairway, Easy car, Linningtons, Contracts 2000.

Typical questions asked were:

'As an IT related company we expect to grow very quickly in the next 12 months with a need for up to 12 vehicles. Could you please provide quotations in respect of two vehicles: a Porsche Boxster 3.2 and Audi A6 Avant 2.7 bi-turbo manual with interior leather. Both to be three years, non-maintenance and maintenance, 12,000 miles pa. Delivery to be immediate.'

'Where is the nearest dealership that we may test drive these models?'

'Please also send me a company brochure explaining your maintenance offerings, track record and company credentials.'

\section{Sector summary}

Contract hire is an industry that needs to sell on price or service but continues to do neither over the Internet. The outright winner of the worst performing sector, contract hire companies continue to offer appalling service. Only one brochure was received from the 19 requested. Still more surprising for a deal-oriented industry, less than a quarter responded to the request for a quotation.

The complete lack of on-line service (with the exception of Cygnet) raises the question why these companies are using valuable advertising space to feature Internet sites or e-mail addresses. Do they not they want to sell or are they successful enough without the need to use or invest in a further sales channel?

The two companies that stood out last time joined the 81 per cent of worst companies which appeared to completely ignore this sales lead. The star performer was Cygnet which sent a brochure within three working days and provided a full quotation within five working days. Vehicle Finance Solutions performed well providing a quote which included a list of local dealers and a follow-up e-mail to advise of special deals.

\section{Computers and printers}

The 15 companies surveyed included many of the sector leaders: Canon, Dell, Mesh Computers PLC, Hewlett Packard, Gateway, PC World, Dan, Compaq, NEC direct, Evesham.com, IBM.

Typical questions asked were:

'Do you have any benchmarks of overall performance and reliability for your models (suitable for running Windows 2000) and how they rate against equivalent models from other suppliers? How soon will delivery be, once I've ordered?'

'Please send a brochure that includes your colour laser printer range. Are all these printers compatible with Windows 2000?' 


\section{Table 2}

\section{CONTRACT HIRE}

\begin{tabular}{|c|c|c|c|}
\hline & Sector & Sector & All \\
\hline & December & May & companies \\
\hline & 1999 & 2000 & May 2000 \\
\hline Per cent advertising websites only & 27 & 14 & 78 \\
\hline Per cent advertising e-mail addresses only & 18 & 52 & 6 \\
\hline Per cent advertising both & 55 & 33 & 16 \\
\hline \multicolumn{4}{|l|}{ Contactability } \\
\hline Per cent websites did not work & 0 & 0 & 6 \\
\hline Per cent e-mail did not work & 9 & 5 & 4 \\
\hline Per cent no way of asking questions & 0 & 10 & 23 \\
\hline Per cent no way of requesting brochures & 0 & 10 & 15 \\
\hline \multicolumn{4}{|l|}{ Request for brochures } \\
\hline Average number of days to receive brochure & 3.0 & 3.0 & 5.1 \\
\hline Per cent brochures not received & 90 & 95 & 48 \\
\hline Per cent received next day & 0 & 0 & 1 \\
\hline Per cent received within two working days & 0 & 0 & 13 \\
\hline $\begin{array}{l}\text { Per cent received between two and five } \\
\text { working days }\end{array}$ & 10 & 5 & 24 \\
\hline Per cent received after five working days & 0 & 0 & 14 \\
\hline Per cent with correct name and address & 100 & 100 & 91 \\
\hline \multicolumn{4}{|l|}{ Request for product service information } \\
\hline Per cent of organisations asked questions & 91 & 90 & 77 \\
\hline Per cent where full answers received & 50 & 16 & 32 \\
\hline Per cent where part answers received & 10 & 5 & 17 \\
\hline Per cent where inappropriate answer received & 0 & 0 & 10 \\
\hline Per cent where no answer was received & 40 & 79 & 41 \\
\hline Per cent answering the same day & 20 & 0 & 28 \\
\hline Per cent answering the next working day & 0 & 16 & 15 \\
\hline Per cent answering the second working day & 10 & 0 & 6 \\
\hline Per cent answering in two to five working days & 30 & 5 & 4 \\
\hline Per cent answering after five working days & 0 & 0 & 7 \\
\hline Per cent best & 0 & 0 & 8 \\
\hline Per cent worst & 36 & 81 & 41 \\
\hline
\end{tabular}


Table 3

\section{COMPUTERS AND PRINTERS}

Per cent advertising websites only

Per cent advertising e-mail addresses only

Per cent advertising both

\section{Contactability}

Per cent website did not work

Per cent e-mail did not work

Per cent no way of asking questions

Per cent no way of requesting brochures

\section{Request for brochures}

Average number of days to receive brochure

Per cent brochures not received

Per cent received next day

Per cent received within two working days

Per cent received between two to five

$$
\text { working days }
$$

Per cent received after five working days

Per cent with correct name and address

\section{Request for product service information}

Per cent of organisations asked questions

Per cent where full answers received

Per cent where part answers received

Per cent where inappropriate answer received

Per cent where no answer was received

Per cent answering the same day

Per cent answering the next working day

Per cent answering the second working day

Per cent answering in two to five working days

Per cent answering after five working days

Per cent best

Per cent worst

$\begin{array}{lll}\text { Sector } & \text { Sector } & \text { All } \\ \text { December } & \text { May } & \text { companies } \\ 1999 & 2000 & \text { May 2000 }\end{array}$

$\begin{array}{rrr}93 & 80 & 78 \\ 0 & 0 & 6 \\ 13 & 20 & 16\end{array}$

$\begin{array}{rrr}0 & 7 & 6 \\ 7 & 7 & 4 \\ 0 & 20 & 23 \\ 0 & 7 & 15\end{array}$

$\begin{array}{rrr}2.2 & 4.7 & 5.1 \\ 54 & 57 & 48 \\ 8 & 7 & 1 \\ 23 & 14 & 13 \\ 15 & 7 & 24 \\ & & \\ 0 & 14 & 14 \\ 83 & 100 & 91\end{array}$

$\begin{array}{rrr}80 & 80 & 77 \\ 50 & 17 & 32 \\ 17 & 8 & 17 \\ 0 & 8 & 10 \\ 33 & 67 & 41 \\ 17 & 17 & 28 \\ 17 & 8 & 15 \\ 17 & 0 & 6 \\ 17 & 0 & 4 \\ 0 & 8 & 7 \\ & & \\ 26 & 7 & 8 \\ 26 & 60 & 41\end{array}$




\section{Sector summary}

This sector qualified as the third worst performing with a marked deterioration from a sparkling performance in January. Then a clear schism was noted between the best computer companies, an impressive 26 per cent who all set a cracking pace, and an equal number of worst companies which included many of the sector leaders.

Following the second survey there was only one star performer, Dan, which set a shining example of what could be achieved by responding to questions on the same day and providing a brochure within two working days. As with the Internet service providers (ISPs), it was wondered if brimming sales pipelines explained the apparent disinterest in additional new business.

Hewlett Packard had an outstanding website with the emphasis on buying on-line. They provided answers to questions, delivery times and telephone numbers for local dealers for any mopping up.

\section{Adult entertainment}

The ten companies surveyed were: Personal Pleasure, Xesshop, Xnet, Skin Two, Blue Snake, Your Choice, Transformation, Gentleman's Locker, Bizarre, Dateline. Typical questions asked were:

'Can you also tell me if you are a member of ASACP (adult sites against child pornography) or any similar organisation?'
'Are all products delivered in discreet packaging?'

'I'd like to know more about your magazine and any other product lines you may have. Please send a flyer/brochure to me at the address below.'

'Please tell me what will appear on my credit bill should I buy from you.'

\section{Sector summary}

Adult entertainment continued to be a clear leader in quick and effective responses. Two out of three companies answered the questions fully with 55 per cent of these on either the same or next working day. In this respect they performed better than the overall average and hold the joint first position of best sector with business schools and home furnishings.

When it came to hard copy media however, the sector was not so efficient. It took an average of six and a half days to receive brochures and 43 per cent of requests were not fulfilled.

Gentleman's Locker answered the question the same day and provided an explanation as to why they do not provide a brochure. They informed the researchers that the catalogue is the website enabling them to keep the product range up-to-date while keeping costs down. It also provides complete anonymity. 
Table 4

ADULT ENTERTAINMENT

\begin{tabular}{|c|c|c|c|}
\hline & $\begin{array}{l}\text { Sector } \\
\text { December } \\
1999\end{array}$ & $\begin{array}{l}\text { Sector } \\
\text { May } \\
2000\end{array}$ & $\begin{array}{l}\text { All } \\
\text { companies } \\
\text { May } 2000\end{array}$ \\
\hline Per cent advertising websites only & 10 & 80 & 78 \\
\hline Per cent advertising e-mail addresses only & 90 & 0 & 6 \\
\hline Per cent advertising both & 40 & 20 & 16 \\
\hline \multicolumn{4}{|l|}{ Contactability } \\
\hline Per cent website did not work & 0 & 0 & 6 \\
\hline Per cent e-mail did not work & 10 & 10 & 4 \\
\hline Per cent no way of asking questions & 20 & 10 & 23 \\
\hline Per cent no way of requesting brochures & 0 & 10 & 15 \\
\hline \multicolumn{4}{|l|}{ Request for brochures } \\
\hline Average number of days to receive brochure & 6.0 & 6.5 & 5.1 \\
\hline Per cent brochures not received & 50 & 43 & 48 \\
\hline Per cent received next day & 0 & 0 & 1 \\
\hline Per cent received within two working days & 0 & 0 & 13 \\
\hline $\begin{array}{l}\text { Per cent received between two to five } \\
\text { working days }\end{array}$ & 10 & 43 & 24 \\
\hline Per cent received after five working days & 30 & 14 & 14 \\
\hline Per cent with correct name and address & 100 & 100 & 91 \\
\hline \multicolumn{4}{|l|}{ Request for product service information } \\
\hline Per cent of organisations asked questions & 90 & 90 & 77 \\
\hline Per cent where full answers received & 78 & 67 & 32 \\
\hline Per cent where part answers received & 11 & 0 & 17 \\
\hline Per cent where inappropriate answer received & 0 & 0 & 10 \\
\hline Per cent where no answer was received & 11 & 33 & 41 \\
\hline Per cent answering the same day & 33 & 44 & 28 \\
\hline Per cent answering the next working day & 44 & 11 & 15 \\
\hline Per cent answering the second working day & 0 & 0 & 6 \\
\hline Per cent answering in two to five working days & 11 & 0 & 4 \\
\hline Per cent answering after five working days & 0 & 11 & 7 \\
\hline Per cent best & 0 & 20 & 8 \\
\hline Per cent worst & 10 & 30 & 41 \\
\hline
\end{tabular}




\section{Personal finance, investments and stock dealing}

The 37 companies surveyed included: Aberdeen, Alliance \& Leicester, Bank of Scotland, Barclays, Citibank, DLJ Direct, EGG, E-Loan, Gartmore, Halifax, Henderson, Johnson Fry, Jupiter, Killick \& Co, Legal and General, Lloyds TSB, Marble, M\&G, Nationwide, Norwich Union, Perpetual, Schroders, Scottish Widows Bank, Sharepeople Ltd, Standard Life Bank, Union CAL, Virgin One.

Typical questions asked were:

'I've recently inherited $£ 5,000$ which I'd like to invest as soon as possible. Please send me a brochure on your equity trading services. Should I need to trade urgently and at short notice, is there a guarantee of availability of service?'

'What is the current rate of interest on balances of $£ 5,000$ and over? What is the charge for cheque processing should my account temporarily fall below the $£ 5,000$ threshold? Please send me a business account information pack.'

'How often can I change my ISA holdings with a self select ISA? Can I trade on-line?'

\section{Sector summary}

What a difference from the last survey. In January this sector led the field in on-line service, in the third survey they ranked a poor fifth. There was an overall deterioration in infor- mation received. Three out of four companies, including many high street names, failed to send a brochure or answer the questions. The e-Brands, as in January, did not perform better than their traditional competitors. Of the high street names that did respond, there was still a focus around call rather than customer-interaction centres. As with business travel, the phone may be the best way to deal with a complex enquiry such as a combined bank account and mortgage. Concerning accessibility, 22 per cent of companies provided no means of asking questions and 11 per cent no means of requesting a brochure.

The star performers were Johnson Fry, Schroders, Sharepeople Ltd and Gartmore. They all provided a full answer to the questions and literature was received within three days.

This sector also proves that it is possible to invest significant amounts in web marketing and sales and to mismanage 89 per cent of all enquiries.

\section{Cars}

The 15 companies surveyed included many of the sector leaders: Alfa Romeo, BMW, Ford, Honda, Jeep, Mazda, Mercedes, Mitsubishi, Peugeot, Renault, Rover, Saab, Suzuki, Toyota and Volvo.

Typical questions asked were:

'I'd like to book a test drive please e-mail me if this is possible (I'm away on business, but picking up my e-mails regularly).' 
Table 5

PERSONAL FINANCE, INVESTMENTS AND STOCK DEALING

\begin{tabular}{|c|c|c|c|}
\hline & $\begin{array}{l}\text { Sector } \\
\text { December } \\
1999\end{array}$ & $\begin{array}{l}\text { Sector } \\
\text { May } \\
2000\end{array}$ & $\begin{array}{l}\text { All } \\
\text { companies } \\
\text { May } 2000\end{array}$ \\
\hline Per cent advertising websites only & 86 & 97 & 78 \\
\hline Per cent advertising e-mail addresses only & 3 & 0 & 6 \\
\hline Per cent advertising both & 8 & 3 & 16 \\
\hline \multicolumn{4}{|l|}{ Contactability } \\
\hline Per cent website did not work & 3 & 5 & 6 \\
\hline Per cent e-mail did not work & 35 & 3 & 4 \\
\hline Per cent no way of asking questions & 14 & 22 & 23 \\
\hline Per cent no way of requesting brochures & 0 & 11 & 15 \\
\hline \multicolumn{4}{|l|}{ Request for brochures } \\
\hline Average number of days to receive brochure & 2.4 & 4.4 & 5.1 \\
\hline Per cent brochures not received & 27 & 31 & 48 \\
\hline Per cent received next day & 12 & 0 & 1 \\
\hline Per cent received within two working days & 42 & 21 & 13 \\
\hline $\begin{array}{l}\text { Per cent received between two to five } \\
\text { working days }\end{array}$ & 12 & 24 & 24 \\
\hline Per cent received after five working days & 6 & 24 & 14 \\
\hline Per cent with correct name and address & 92 & 85 & 91 \\
\hline \multicolumn{4}{|l|}{ Request for product service information } \\
\hline Per cent of organisations asked questions & 65 & 78 & 77 \\
\hline Per cent where full answers received & 67 & 31 & 32 \\
\hline Per cent where part answers received & 29 & 21 & 17 \\
\hline Per cent where inappropriate answer received & 0 & 7 & 10 \\
\hline Per cent where no answer was received & 4 & 41 & 41 \\
\hline Per cent answering the same day & 42 & 31 & 28 \\
\hline Per cent answering the next working day & 25 & 7 & 15 \\
\hline Per cent answering the second working day & 17 & 10 & 6 \\
\hline Per cent answering in two to five working days & 8 & 7 & 4 \\
\hline Per cent answering after five working days & 0 & 3 & 7 \\
\hline Per cent best & 22 & 11 & 8 \\
\hline Per cent worst & 2 & 30 & 41 \\
\hline
\end{tabular}


CARS

\begin{tabular}{|c|c|c|c|}
\hline & $\begin{array}{l}\text { Sector } \\
\text { December } \\
1999\end{array}$ & $\begin{array}{l}\text { Sector } \\
\text { May } \\
2000\end{array}$ & $\begin{array}{l}\text { All } \\
\text { companies } \\
\text { May } 2000\end{array}$ \\
\hline Per cent advertising websites only & 100 & 100 & 78 \\
\hline Per cent advertising e-mail addresses only & 0 & 0 & 6 \\
\hline Per cent advertising both & 0 & 0 & 16 \\
\hline \multicolumn{4}{|l|}{ Contactability } \\
\hline Per cent website did not work & 0 & 13 & 6 \\
\hline Per cent e-mail did not work & 67 & 0 & 4 \\
\hline Per cent no way of asking questions & 0 & 20 & 23 \\
\hline Per cent no way of requesting brochures & 0 & 0 & 15 \\
\hline \multicolumn{4}{|l|}{ Request for brochures } \\
\hline Average number of days to receive brochure & 6.0 & 7.7 & 5.1 \\
\hline Per cent brochures not received & 33 & 20 & 48 \\
\hline Per cent received next day & 7 & 0 & 1 \\
\hline Per cent received within two working days & 7 & 7 & 13 \\
\hline $\begin{array}{l}\text { Per cent received between two to five } \\
\text { working days }\end{array}$ & 20 & 47 & 24 \\
\hline Per cent received after five working days & 27 & 27 & 14 \\
\hline Per cent with correct name and address & 100 & 92 & 91 \\
\hline \multicolumn{4}{|l|}{ Request for product service information } \\
\hline Per cent of organisations asked questions & 100 & 80 & 77 \\
\hline Per cent where full answers received & 0 & 25 & 32 \\
\hline Per cent where part answers received & 73 & 33 & 17 \\
\hline Per cent where inappropriate answer received & 7 & 8 & 10 \\
\hline Per cent where no answer was received & 20 & 33 & 41 \\
\hline Per cent answering the same day & 7 & 8 & 28 \\
\hline Per cent answering the next working day & 20 & 17 & 15 \\
\hline Per cent answering the second working day & 0 & 17 & 6 \\
\hline Per cent answering in two to five working days & 20 & 8 & 4 \\
\hline Per cent answering after five working days & 33 & 17 & 7 \\
\hline Per cent best & 0 & 0 & 8 \\
\hline Per cent worst & 20 & 13 & 41 \\
\hline
\end{tabular}


'My current car lease expires in the first week of July, can you tell me if a Grand Cherokee 3.1 TD can be delivered by this time?'

'Can you tell me if BMW have an environmental policy re issues such as emissions and recycling?'

\section{Sector summary}

On-line service in the car sector continued to be very mixed. The average response times to brochure requests is misleading, distorted by Mercedes whose brochure was received after 24 working days and Alfa Romeo, a close second, at 23 working days. The bulk of the brochures were received between two and five working days, a significant improvement from January.

Passing customer information to local dealers continues to cause problems. Although Renault, Jeep, Mazda, Saab and Mercedes appear to manage this well - all their dealers contacted the researchers using a mix of e-mail, telephone or in writing. But two-thirds of local dealers failed to contact the researchers to arrange a test drive.

The Mercedes, BMW and Suzuki websites channelled us to contact the local dealers direct. A good but flawed idea as the researchers only heard from one, Mercedes, who provided a comprehensive response the next working day.

\section{Food, drink and cosmetics}

The 14 companies surveyed were: Jack Daniels, Clarins, Dior, Inis, Paco Rabane, Kms, Clinique, Nivea, Island
Trading, Chocolate Store, The Fresh Food Co, Kerastase, Chanel, Pantene.

Typical questions asked were:

'After reading a magazine article, I've decided I need urgently to improve my skin care regime. Please send me a brochure on your range of skin care products. Are any of the men's products eg men's 3step/chemistry/etc, available as a gift set?'

'I require a regular delivery of organic goods, beginning as soon as possible. Please send a brochure on your range of products. I'd like to include fresh bread with the order, how long after baking will delivery be to my house?'

\section{Sector summary}

Overall, there was above average service from a sector where costs and margins are an issue. At the highmargin end, Clarins and the Fresh Food Co were the top performers and spot on in their responses. This begs the question why, in a me-too industry, the other large cosmetic houses such as Chanel, Dior and Clinique are not providing the same level of service as Clarins.

The Chocolate Store retails exclusively on-line with a fully illustrated website and belong to a Web trader code of practice. The researchers received a courteous and fully answered response the next working day, they even thanked the researchers for the enquiry. They did not qualify 
FOOD, DRINK AND COSMETICS

\begin{tabular}{|c|c|c|c|}
\hline & $\begin{array}{l}\text { Sector } \\
\text { December } \\
1999\end{array}$ & $\begin{array}{l}\text { Sector } \\
\text { May } \\
2000\end{array}$ & $\begin{array}{l}\text { All } \\
\text { companies } \\
\text { May } 2000\end{array}$ \\
\hline Per cent advertising websites only & 94 & 100 & 78 \\
\hline Per cent advertising e-mail addresses only & 0 & 0 & 6 \\
\hline Per cent advertising both & 6 & 0 & 16 \\
\hline \multicolumn{4}{|l|}{ Contactability } \\
\hline Per cent website did not work & 0 & 7 & 6 \\
\hline Per cent e-mail did not work & 6 & 0 & 4 \\
\hline Per cent no way of asking questions & 0 & 29 & 23 \\
\hline Per cent no way of requesting brochures & 0 & 29 & 15 \\
\hline \multicolumn{4}{|l|}{ Request for brochures } \\
\hline Average number of days to receive brochure & 5.0 & 3.5 & 5.1 \\
\hline Per cent brochures not received & 71 & 60 & 48 \\
\hline Per cent received next day & 7 & 0 & 1 \\
\hline Per cent received within two working days & 7 & 20 & 13 \\
\hline $\begin{array}{l}\text { Per cent received between two to five } \\
\text { working days }\end{array}$ & 7 & 10 & 24 \\
\hline Per cent received after five working days & 7 & 10 & 14 \\
\hline Per cent with correct name and address & 100 & 100 & 91 \\
\hline \multicolumn{4}{|l|}{ Request for product service information } \\
\hline Per cent of organisations asked questions & 81 & 71 & 77 \\
\hline Per cent where full answers received & 31 & 40 & 32 \\
\hline Per cent where part answers received & 8 & 20 & 17 \\
\hline Per cent where inappropriate answer received & 0 & 30 & 10 \\
\hline Per cent where no answer was received & 62 & 10 & 41 \\
\hline Per cent answering the same day & 23 & 50 & 28 \\
\hline Per cent answering the next working day & 0 & 20 & 15 \\
\hline Per cent answering the second working day & 8 & 0 & 6 \\
\hline Per cent answering in two to five working days & 8 & 10 & 4 \\
\hline Per cent answering after five working days & 8 & 10 & 7 \\
\hline Per cent best & 12 & 14 & 8 \\
\hline Per cent worst & 43 & 36 & 41 \\
\hline
\end{tabular}


as a top performing company because they do not provide a brochure, however, is a brochure really necessary as they offer a fully illustrated website?

At the time of the survey, Nivea did not offer gift packs for men. Instead they provided a free sponge bag and money off vouchers to enable a personalised gift set to be put together from the range of men's products. This was very customer-focused, although at what cost to the company?

\section{IMPLICATIONS OF THE SURVEY}

Customer service levels in the UK e-commerce sector still have huge room for improvement. Simply putting a website on-line is not enough. On-line service requires both good web content and a back-end infrastructure that will ensure action.

The large brands working through local distributors continue to face the hardest challenge. How do they square the circle of direct communications to customers with third-party distribution while maintaining prices and service standards consistent with brand values? Added to this is the challenge that most Internet users have higher than average service expectations (an accurate response to enquiries is at the top of most Internet customers' requirements). The poor customer service offered through the vast majority of websites devalues carefully and expensively constructed brand values. The risk to established brand leaders is greatest as they have more to lose.
The theory is that high service levels enable customers to build trust and buy again. The economics of customer acquisition (marketing costs as high as $\mathcal{K}^{46}$ per $\mathcal{E} 1$ gross profit have already been noted) mean that repeat and referral business is essential. Evidence of this is in a study from Bain \& Company and Mainspring, which found that in the clothing industry repeat customer's spend 67 per cent more in the third year of visiting a site than in the first six months.

But the authors' survey shows that the biggest winner for most companies is to succeed on-line much earlier in the customer life cycle. If pre-sales service to hot prospects is improved there is the opportunity significantly to raise on-line generated sales. Anecdotal evidence from Brightware (based on a sample of their US financial services clients) is that 98 per cent of financial service sales on the Internet generate an e-mail and that responding within an hour increases propensity to buy by 75 per cent.

The current state of play in the UK is so feeble that the one in 12 companies which manage on-line sales leads well have an opportunity to win business in a channel with little real competition. If they can keep costs down, increase sales and improve their brand then they will be in an overall winning position. For the rest, the choice is whether to reduce on-line sales and marketing spend or to tighten up their website operations and score in a still open playing field. 
Going back to the theory of web economics, the survey findings call into doubt the ability of most companies to exploit repeat business on-line. The infrastructure and processes to deal with repeat business, assuming that the customer will give them a second try, is almost completely lacking.

Many industries are still unable to pass on web enquiries to their own field sales forces. In the automotive sector, two out of three local dealers failed to contact the researchers to arrange a test drive.

In some sectors, such as personal finance and business travel, an explicit strategy is emerging to point Web users towards phoning for complex enquiries while making it impossible to enquire on-line. Whether this approach is a compromise or an outright winner, any strategy that manages Web users' service expectations must be better than the wall of silence that currently greets 41 per cent of all Web enquiries.

\section{CONCLUSION}

The survey focused on a qualitative analysis of e-business rather than integration issues. The sheer volume of indifferent performance revealed by the survey says a lot about the current situation. At a time when structural differences in the dynamics of US and European economies are being highlighted careful thought needs to be given, not just to high-flown 360degree CRM philosophies but also to the real-world execution of customer management strategies. For UK PLC, the issue is whether overseas competitors are wasting as much money at an equivalent rate. 